\title{
The Diagnostic and Prognostic Value of Magnetic Resonance Imaging for Evaluating Atypical Inflammatory Demyelinating Lesions
} Atipik Enflamatuvar Demiyelinizan Lezyonların Değerlendirilmesinde Manyetik
Rezonans Görüntülemenin Diagnostik ve Prognostik Önemi

\author{
(D) Zeynep Özdemir ${ }^{1}$, (1) Erkan Acar², (1) Aysun Soysal ${ }^{1}$ \\ 1 Istanbul Bakirkoy Prof. Dr. Mazhar Osman Mental Health and Neurological Diseases Training and Research Hospital, Clinic of Neurology, \\ Istanbul, Turkey \\ 2Acibadem Mehmet Ali Aydınlar University Faculty of Medicine, Department of Neurology, Istanbul, Turkey
}

\begin{abstract}
Objective: The diagnosis of patients with atypical demiyelinating lesions has always been challenging, sometimes leading to a biopsy. Recent literature has radiologically classified atypical inflammatory demyelinating lesions as ring-like, Balo-like, infiltrative, megacystic, and unclassified lesions. In this study, we aimed to assess the demographics and clinical and radiologic findings in patients with atypical lesions.

Materials and Methods: The records of 320 patients with demyelinating disorders were retrospectively assessed using iMed database. Patients with atypical lesions and whose magnetic resonance imaging evaluations were included. Clinical and radiologic findings were evaluated and lesions were classified according to the recommended criteria.

Results: Twenty-seven patients (16 females) were included and the mean age was 34.26 0.12 (range: 26-49) years. Fourteeen patients had ring-like, three had Balo-like, three had megacystic, five had infiltrative, and two patients had unclassified lesions. Diffusion restriction was observed in contrast-enhancing sites in ring-like lesions, heterogeneously in infiltrative lesions and also peripherally in Balo-like lesions. Two patients with infiltrative lesions had additional lesions on follow-up and had to undergo biopsy. Two patients died despite aggressive treatment. Two patients with Balo-like lesions were evaluated as having acute disseminated encephalomyelitis and did not have further relapses. Seventeen patients from the study group converted to multiple sclerosis (MS) on follow-up.

Conclusion: Differential diagnosis of atypical inflammatory demyelinating lesions is not always easy, the prognosis is not different from MS lesions. Mostly, ringlike lesions seem to convert to MS with recurrent relapses; however, infiltrative lesions seem to have poorer outcomes, especially if patients have additional relapses. Keywords: Multiple sclerosis, magnetic resonance imaging, atypical inflammatory demyelinating lesions
\end{abstract}

Öz

Amaç: Tipik olmayan demiyelinizan lezyonlar ile prezente olan hastaların tanısı zaman zaman biyopsi gerektirecek kadar zor olabilmektedir. Son yayınlarda atipik enflamatuvar demiyelinizan lezyonlar radyolojik olarak 5 ana sınıfta tanımlanmıştır: Halka benzeri, balo benzeri, infiltratif, megakistik ve sınıflandırılamayandır. Bu çalışmada atipik lezyonlara sahip hastaları demografik, klinik ve radyolojik olarak değerlendirmeyi amaçladık.

Gereç ve Yöntem: iMed veritabanı kullanılarak demiyelinizan hastalık tanısı ile izlenmekte olan 320 hasta retrospektif olarak değerlendirildi. Çalışmaya manyetik rezonans görüntülemesi olan ve atipik demiyelinizan lezyona sahip olan hastalar dahil edildi. Klinik ve radyolojik bulgular değerlendirildi ve lezyonlar önerilen kriterlere göre sınıflandırıldı.

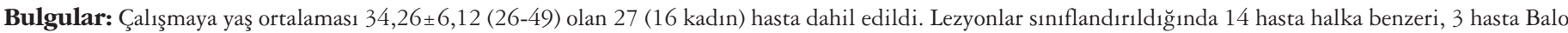
benzeri, 3 hasta megakistik, 5 hasta infiltratif, 2 hasta sınıflandırılamayan atipik demiyelinizan lezyonlara sahipti. Difüzyon ağırlıklı serileri bulunan görüntüler değerlendirildiğinde, Balo benzeri lezyonların etrafında, infiltratif lezyonlarda heterojen şekilde ve halka benzeri lezyonların kontrast tutulumu olan bölgelerinde aynı zamanda difüzyon kısıtlılı̆̆ hastalara biyopsi yapılmak zorunda kalınıldı. İki hasta agresif tedaviye rağmen kaybedildi. Balo benzeri lezyonu olan hastaların 2 tanesinin relapsı olmadı ve

Address for Correspondence/Yazışma Adresi: Zeynep Özdemir MD, Istanbul Bakirkoy Prof. Dr. Mazhar Osman Mental Health and Neurological Diseases Training and Research Hospital, Clinic of Neurology, Istanbul, Turkey

Tel.: +90 2124091515 (1840) E-posta: zynp.ozdemir@hotmail.com ORCID: orcid.org/0000-0002-6403-4133

Received/Geliş Tarihi: 04.03.2020 Accepted/Kabul Tarihi: 07.01.2021 
kliniği akut disemine ensefalomiyelit olarak değerlendirildi. Çalışma grubundaki 17 hasta takiplerinde klinik olarak multipl skleroz (MS) tanısı ile halen takip edilmektedir.

Sonuç: Her ne kadar atipik enflamatuvar demiyelinizan lezyonların ayırıcı tanısı her zaman kolay olmasa da, prognozları MS lezyonlarından çok farklı değildir. Genellikle halka benzeri lezyonlar rekürren relapsları olan MS'ye dönüşmekteyken, özellikle relapsları olan infiltratif lezyonlu hastaların prognozu kötü olmaktadır. Anahtar Kelimeler: Multpil skleroz, manyetik rezonans görüntüleme, atipik enflamatuvar demiyelinizan lezyonlar

\section{Introduction}

Inflammatory demyelinating diseases (IDD) of the central nervous system are examined in a wide spectrum, and apart from well-defined diseases, atypical magnetic resonance imaging (MRI) that sometimes complicate the diagnosis can be encountered. According to the revised McDonald criteria published in 2017, typical multiple sclerosis (MS) lesions are defined as juxtacortical, periventricular, infratentorial lesions larger than 3 millimeters, oval and/or ovoid-shaped, and perpendicular to the ventricles defined as "Dawson fingers".

In recent years, with the development of MRI technologies, central vein findings showing the veins passing through MS lesions located around the veins or the presence of ependymal dot-dash sign defined as hyperintense points (dots) on the callososeptal surface and hypointense areas (dashes) between them in thin-section sagittal fluid-attenuated inversion recovery (FLAIR) weighted images strengthen the aforementioned lesions to be associated with MS $(1,2)$. In neuromyelitis optica (NMO) and spectrum diseases where the lesions are mostly diencephalic, typical MS-like lesions can be seen located near the corticospinal tract, in the brainstem or hemispheric, but atypical lesions can also be seen (3).

Although rare, typical MS lesions can be seen in acute disseminated encephalomyelitis (ADEM), in which lesions located below and above the tentorium are more bilateral, asymmetrical, and with irregular borders. In addition to these, atypical lesions are more seen compared to typical MS lesions in concentric sclerosis of Balo, where lesions are observed larger than $2 \mathrm{~cm}$, mostly hemispheric, rarely in the form of intertwined lamellae located in the brainstem and spinal cord, and Marburg-type MS variants, where very large lesions are seen. In addition, these atypical lesions can be seen both in the course of MS and in NMO and ADEM diseases, albeit rarely.

Although lesions that are frequently encountered in demyelinating diseases of the central nervous system and have higher specificity for the disease are defined, from time to time, atypical appearances with large and mass effect, irregular, unclear lesion boundaries and heterogeneity, ring-shaped or with different contrast material involvement can be encountered $(4,5)$. Seewann et al. (6) reviewed the literature in 2008 and tried to classify IDD with atypical MR features. After reviewing the MRIs of 69 patients with ADEM, NMO or MS, they defined the lesions with contrast enhancement in the form of complete and closed ring as "ringlike"; very large $(>3 \mathrm{~cm})$ and cyst-like lesions as "megacystic"; lesions with heterogeneity in the appearance of 2 or more bands in them as "Balo-like", lesions with a mass effect and an unusual enhancement pattern as "infiltrative", and lesions with irregular and ambiguous morphology that did not meet other definitions as "unclassified" lesions. The researchers reported that this classification of atypical IDD might help differential diagnosis and future classifications, but this should be confirmed by prospective studies (6). Koelblinger et al. (7) included diffusion-weighted imaging (DWI) and apparent diffusion coefficient (ADC) of these lesions in a similar study of 42 patients and reported that diffusion restriction was in the outermost region where active inflammation and/or demyelination continued in Balo-like lesions, the region where contrast enhancement was present in ring-like lesions, and in the periphery of the lesion in infiltrative type lesions (7). In this study, it was aimed to evaluate patients with both idiopathic and secondary atypical inflammatory demyelinating lesions (AIDL) followed in our center, clinically and radiologically.

\section{Materials and Methods}

In this study, 320 patients who were followed up in the Neurology Clinic of Bakirkoy Prof. Dr. Mazhar Osman Mental Health and Neurological Diseases Training and Research Hospital, were recorded with the diagnosis of demyelinating diseases of the central nervous system in the hospital database, and whose demographic, clinical, imaging, and follow-up data were entered, were retrospectively screened. Patients were asked to sign an informed consent form that their information and followup would be entered into this database from the moment they were followed up. Some of the authors (Z.Ö, E.A) independently screened the patients' images for compliance with the AIDL criteria, then the compliance of atypical lesions with the defined criteria was reviewed by the independent author (A.S). Twentyseven patients ( 16 females, 11 males) meeting the defined AIDL criteria were identified. The T1, T2 sequences and contrastenhanced series of all patients were examined, and diffusion series of 20 patients were also examined. The size, shape, location, contrast enhancement and pattern, if any, and the presence/ absence of edema was recorded. Patients were examined in terms of rheumatologic, toxic, metabolic, infectious, and vascular aspects with routine blood tests, cerebrospinal fluid (CSF) examinations, and MRI. Demyelinating diseases of the spinal cord were excluded from the study. In the study, lesions were defined as megacystic, Balo-like, infiltrative, ring-like, and unclassified according to the classification defined by Seewann et al. (6).

\section{Statistical Analysis}

Statistical analysis of the demographic data obtained was performed using the Statistical Package for the Social Sciences (SPSS) Ver. 18.0 program.

\section{Results}

\section{Demographic Features}

Twenty-seven patients (16 women) were included in the study and their mean age was $34.26 \pm 6.12$ (range, 26-49) years. Ring-like AIDL was detected in 14 patients, Balo-like in three, megacystic in three, infiltrative in five, and unclassified AIDL in two patients. 
Eighteen patients converted to MS during their follow-up and two died. Three patients were accepted as having ADEM, and one patient with substance-related toxic demyelination did not develop any new lesions in the follow-up. Crohn's disease was detected in the follow-up of one patient and the prognosis of two patients could not be determined because they did not attend the follow-up (Table 1).

\section{Ring-Like Lesions}

Ring-like lesions have been defined as the most common class among AIDLs, and in our study, similar to the literature, they constituted the majority of the lesions. In MRI, they are hypointense in T1 series and hyperintense in T2 series, with closed and/or almost closed ring-shaped contrast enhancement surrounding them. In eight of 10 patients with DWI, lesions were seen hyperintense in the middle of the lesion and a surrounding hyperintense rim was seen in DWI, and they had a hypointense focus and a hyperintense rim around them in ADC. In two patients, the lesions appeared isointense in DWI and hyperintense in ADC. These lesions, seen in 13 patients in our study group, were single or multiple round lesions with annular contrast enhancement, mostly localized in the white matter and parietal lobe. Closed ring-shaped contrast enhancement was observed in all patients except for one patient (Figure 1).

\section{Balo-like Lesions}

Classic MR images of this group, in which demyelinating and accompanying remyelinating areas formed a concentric appearance, included two or more hyperintense rings or intertwined band shapes, together with the circumference of the oldest demyelinated area in the center. DWI-ADC images were present in two patients and they did not have a generalizable character such as ring-like lesions, and heterogeneity was also noticeable in these series. However, this situation was seen more clearly in the contrast series. In the patient group, Balo-like lesions were detected in three patients, and the lesions were in the form of heterogeneous banding and/or incomplete rim rather than the classic concentric full ring appearance. Morphologically, two of these three patients with Balo-like lesions initially presented as having ADEM clinically and were followed a monophasic course in their followup. The third patient transormed to MS clinically and was under follow-up (Figure 2).

\section{Megacystic Lesion}

In the reference literature, megacystic lesions are defined as lesions larger than $3 \mathrm{~cm}$. They are hypointense in T1 series, hyperintense in T2 series, and their cystic parts have the same intensity as CSF. It has been reported that some of these lesions may have expansivity towards cortical convexity and that contrast enhancement may be present in the form of an incomplete frame in contrast-enhanced images. In our patient group, two of the three patients with megacystic lesions had heterogeneous contrast enhancement, and the enhancement pattern was in the form of an open ring in one, and another had heterogeneous gadolinium enhancement. In one patient with DWI-ADC images, the lesion was found to be hyperintense in DWI and hypointense in ADC. DWI-ADC sequence was available only in one patient, since it is not likely to describe common features for this sequence. Two patients showed clinical transformation to MS during follow-up,

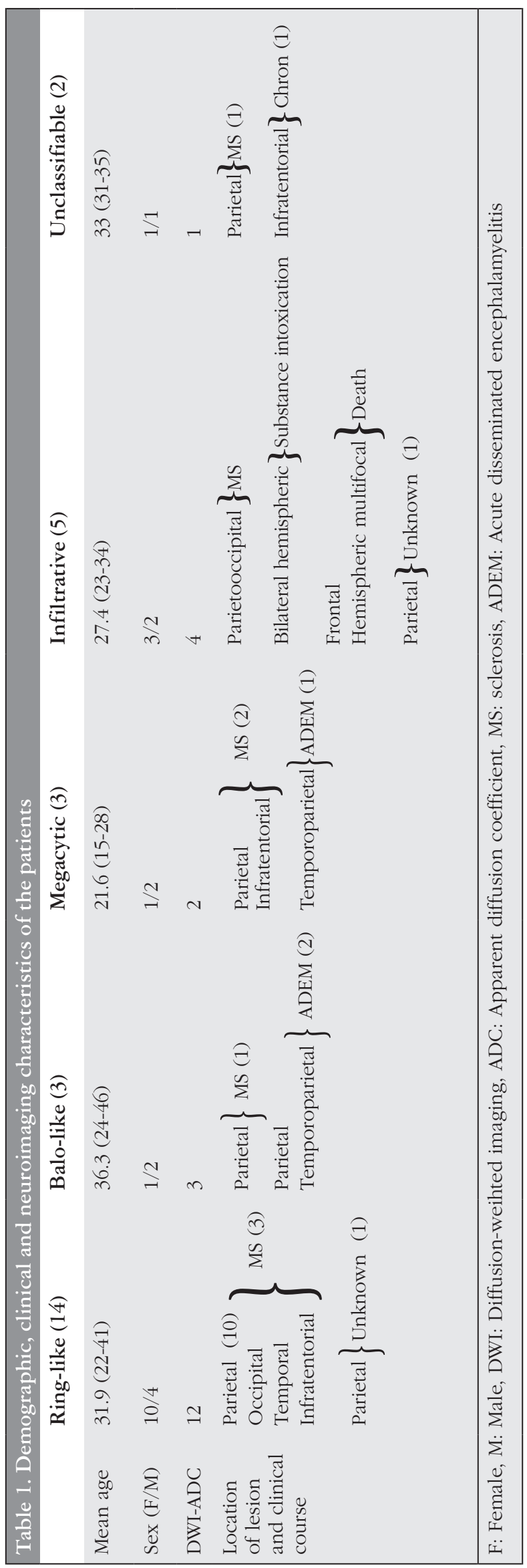




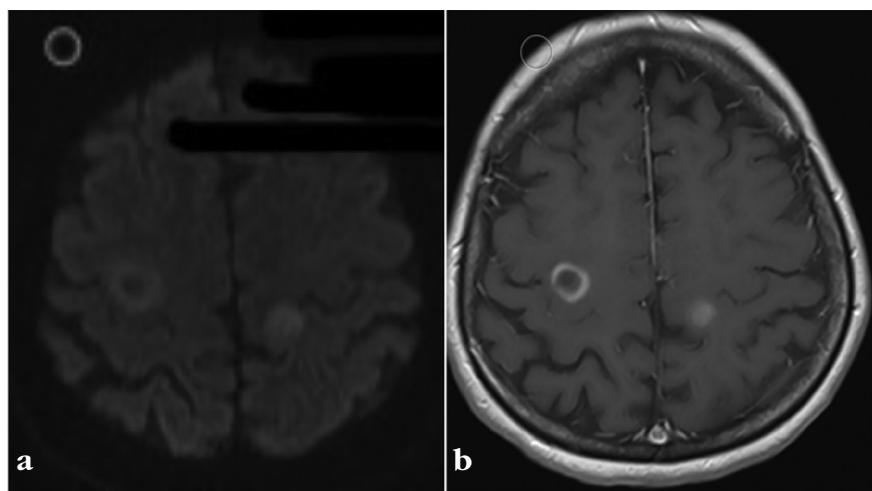

Figure 1. Ring-like AIDL. T1 contrast-enhanced series (a) ring-shaped lesion with contrast enhancement, DWI sequence (b)

DWI: Diffusion-weighted imaging, AIDL: Atypical inflammatory demyelinating lesions

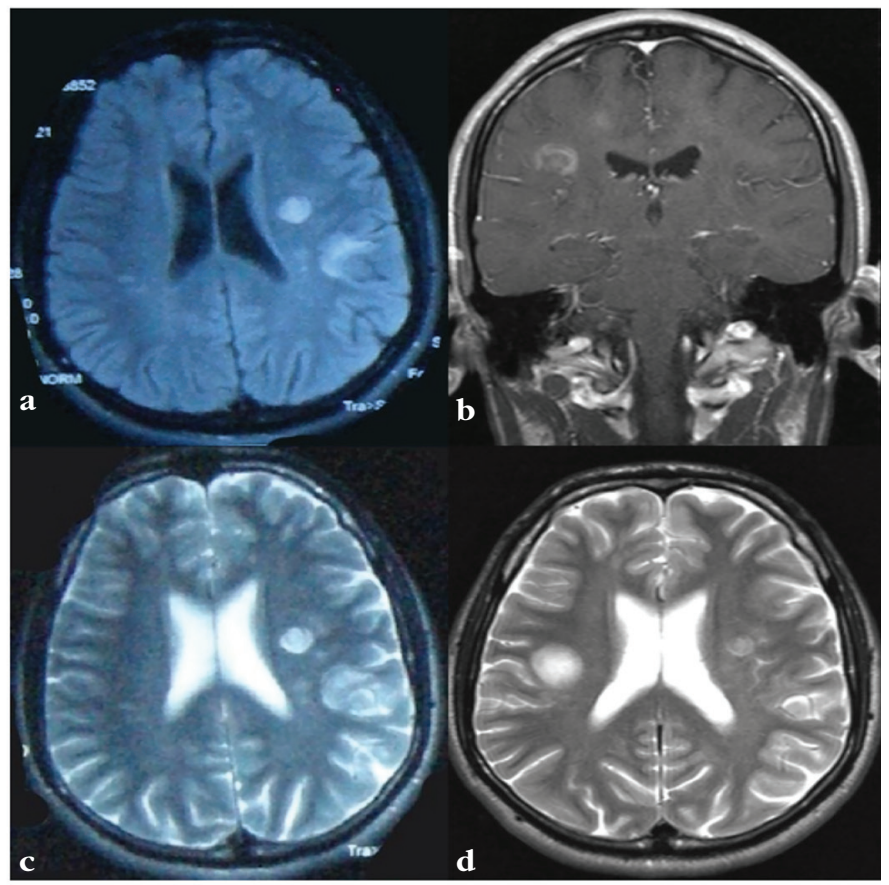

Figure 2. Balo-like AIDL. Image in the form of subcortical interlocking incomplete rims in the FLAIR sequence (a) and T2 sequence (b) of the same patient. In the T2 sequence of another patient (c), multiple lesions with their centers hyperintense and with a hypointense and hyperintense rim around them. Two intertwined hyperintense ring-like lesions in the T1 contrast-enhanced series (d)

FLAIR: Fluid-attenuated inversion recovery, AIDL: Atypical inflammatory demyelinating lesions

and the patient with heterogeneous contrast uptake pattern had no new lesions and was clinically accepted as having ADEM (Figure 3).

\section{Infiltrative Lesion}

The contrast enhancement of these lesions, which are hypointense in T1 series, hyperintense, irregularly demarcated in T2 series, and have more perifocal edema compared with other

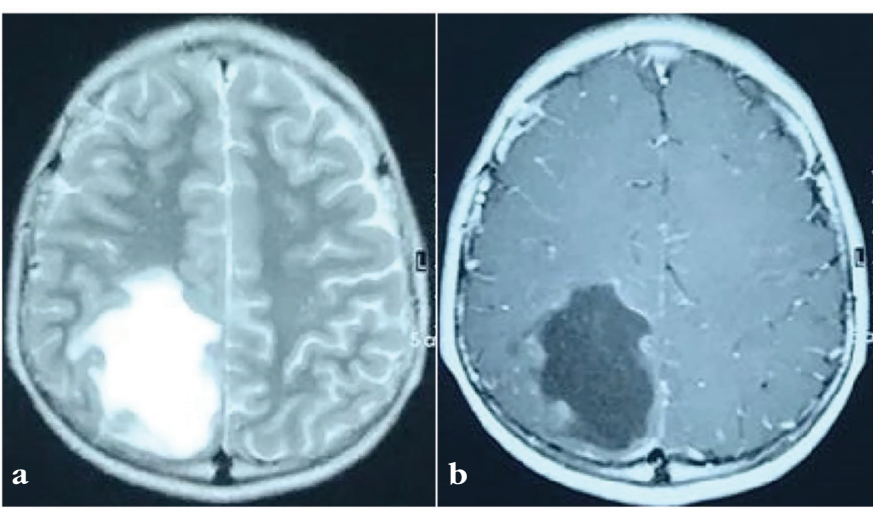

Figure 3. Megacystic AIDL. In FLAIR (a) and T1 contrast (b) series, lesion $>3 \mathrm{~cm}$ that is isointense with CSF. Contrast enhancement is observed around the lesion in the contrast series (b)

CSF: Cerebrospinal fluid, FLAIR: Fluid-attenuated inversion recovery, AIDL: Atypical inflammatory demyelinating lesions

AIDL, is also heterogeneous. In the DWI-ADC images of four patients, mostly hyperechogenic and hypoechogenic areas in both DWI and ADC were noted; however, just as in patients with Balo-like and megacystic lesions, generalizable features were not encountered in DWI-ADC sequences. In the study of Seewann et al. (6), although most of the deaths were in the group that could not be classified, the group with the highest mortality rate in our study group was in the infiltrative group. Diffuse infiltrative lesions were detected in five patients, and two patients needed biopsies, and pathologic findings compatible with demyelinating disease were detected. These two patients died of pneumonia and sepsis during their follow-up. In one patient, toxic demyelination due to substance use was detected as an etiologic factor, and no new lesions were observed in the patient after the discontinuation of synthetic cannabinoid use. Gadolinium enhancement was detected in all patients except for one, who was diagnosed as MS in follow-up. One patient did not attend clinical follow-ups, thus no information was obtained about their prognosis (Figure 4).

\section{Unclassified Lesions}

Among our patient group, AIDL, which could not be classified in accordance with the specified criteria, was detected in only two patients. In one patient in whom the lesion was located infratentorially, there was no DWI-ADC imaging, but it was hyperintense in T2 and FLAIR sequences, hypointense in T1 sequence, and there was no contrast enhancement. When the accompanying systematic symptoms were evaluated during the follow-up of the patient with an immunoglobulin $G$ index of 1.2 and pattern 2 oligoclonal bands, Crohn's disease was diagnosed and the patient was followed up. In the other patient, in addition to typical demyelinating lesions, there was irregularly circumscribed parietally localized hyperintense lesion in T2 and FLAIR sequences. The lesion, which was larger than $5 \mathrm{~mm}$, was isointense in DWI, and hyperintense in ADC with demyelinating character. The patient, who was diagnosed as having clinically definite MS during follow-up, was followed up with appropriate treatment (Figure 5). 


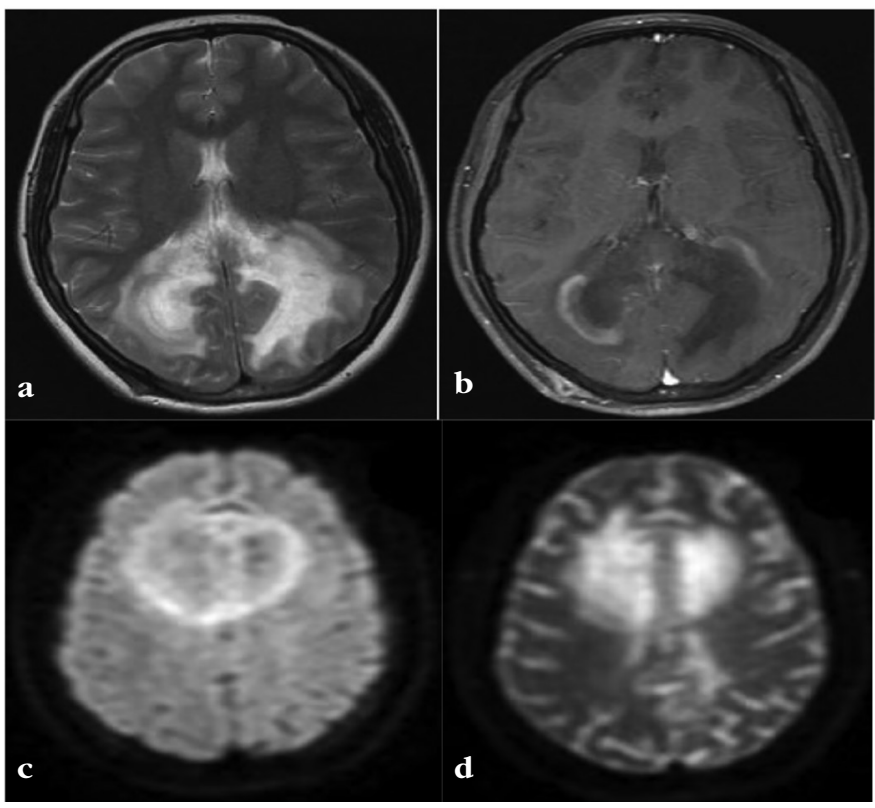

Figure 4. Infiltrative AIDL. The lesion with an irregular border, infiltrative appearance and partial contrast enhancement around the lesion in T2 (a) and T1 contrast-enhanced (b) images of the same patient. Hyperintense and hypointense heterogeneous areas in the DWI (c) image of another patient and a heterogeneous lesion with hyperintense borders in the ADC (d) sequence

AIDL: Atypical inflammatory demyelinating lesions, DWI: Diffusionweighted imaging, ADC: Apparent diffusion coefficient

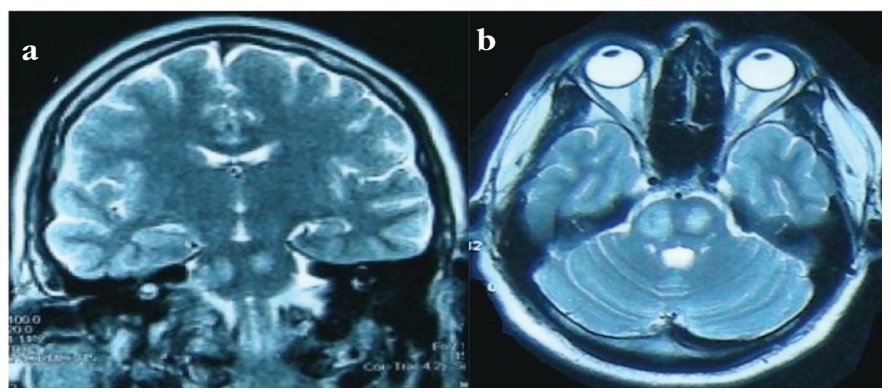

Figure 5. AIDL that cannot be classified. This patient was diagnosed as having Chron's disease in subsequent follow-ups. A lesion with hyperintense heterogeneous areas at pons level in coronal (a) and axial (b) T2 seriesn

AIDL: Atypical inflammatory demyelinating lesions

\section{Discussion}

With the newly developed MRI techniques, many types of clinical, radiologically, and histopathologically different appearances can be encountered in demyelinating diseases. The characteristics of these lesions are important both for determining disease progression and for not overlooking differential diagnoses. In the study conducted by Seewann et al. (6), 270 patients reported in PubMed between 1984 and 2004 and evaluated as atypical were examined and grouped under five main headings as ringlike, Balo-like, megacystic, infiltrative, and unclassified lesions.
Recognition of atypical lesions is very important for conducting etiologic examinations in demyelinating diseases. As defined by the MAGNIMS study group, when lesions identified as "red flags" in the diagnosis of MS are encountered, etiologic examinations should be expanded according to the nature of the lesion (2). In patients with lesions with atypical demyelinating character, toxicmetabolic, infectious, vasculitic and tumoral etiologies should be considered in the foreground and examinations should be detailed. In line with these results, it will be possible to predict which lesion will have an acute inflammatory course and which lesion will have a destructive course, and even prognostic and therapeutic approaches can be established accordingly. In our study, we tried to reveal the clinical course of the patients who met the criteria in the study by Seewann et al. (6) and were followed-up.

Ring-like lesions are frequently encountered during the course of MS. Although its opening in the form of a half-ring facing the cortical area is more suggestive of MS, the closed ring-like contrast enhancement pattern can also be seen in the course of MS, which cannot be underestimated $(8,9)$. Studies have shown that incomplete ring or closed ring-shaped contrast enhancement does not differ histopathologically and it has been suggested that the difference is probably due to the acquisition time of the post-contrast injection MRI sequence and/or the size of the lesion $(10,11)$. Similar to the literature, in our patient series, except for one of the 14 patients with ring-like contrast enhancement on MRI, the remaining 13 patients clinically converted to MS. Based on these data, we think that patients with ring-like lesions have a high risk of conversion to MS if they are followed up clinically; therefore, patients should be followed up closely, clinically and radiologically.

Concentric sclerosing lesions of Balo, which are radiologically seen as an alternating superposition of hyperintense and hypointense lamellae, are pathologically characterized by oligodendrocyte loss. Although the exact pathophysiology cannot be determined clearly, it is thought that these alternating bands may be hypoxic conditioning to protect myelin from serious damage (12,13). Despite the destructive pathophysiologic character of these patients, who were fatal in the years when they were first described, it has been observed clinically that there is a more monophasic and/or benign course in case series $(14,15)$. Plasmapheresis is rarely needed in this form, which shows a good response to intravenous steroids in treatment. In our case series, two of the three patients with Balo-like lesions showed a monophasic course and, although similar demyelinating lesions were not observed in their follow-up, one patient transformed to clinical MS, as in the case series of Wang et al. (16) With the widespread use of MRI, before destruction becomes widespread, it is recognized at earlier stages and the differential diagnosis can be made faster; we think that the urgent initiation of appropriate treatment for patients with Balo-like AIDL may play an important role in the prognosis of patients. However, studies based on larger case series are needed.

Megacystic and inflitrative lesions are more difficult to diagnose than typical demyelinating lesions in terms of their size and contrast enhancement. Investigations for infectious etiologies such as abscesses and tumors such as pilocytic astrocytoma, hemangioblastoma, and metastasis should be prioritized. In terms of the presence of history suggesting an infectious etiology, accompanying neurologic symptoms and deficits such as confusion 
and headache and toxic exposure, examinations should be expanded, and even biopsy should be considered. Histopathologically, cystic lesions with irreversible axonal damage as a result of the decrease in the number of oligodendrocytes and the pronounced T-cell infiltration are rarely seen in multiple sclerosis, although this reflects severe tissue damage (17). In our patient series, a total of three patients with megacystic lesions were diagnosed as having demyelinating disease through biopsy. One patient was clinically diagnosed as having ADEM, and no additional lesions or attacks were observed during the follow-up. However, the other two patients converted to clinical MS. When lesions were seen, these patients had deficits clinically and responded well to corticosteroids; no sequela was observed after the attack.

It is known that early and high-dose methylprednisolone treatment provides up to $80 \%$ full recovery in both ADEM and demyelinating diseases such as MS $(18,19,20)$. In a laboratory study, it was shown that early administration of high-dose corticosteroid treatment reduced the expression of adhesion molecules and proinflammatory cytokines (21). Based on this idea, it is suggested that early and high-dose steroid treatment might positively affect long-term survival and morbidity by reducing tissue damage, but more clinical and laboratory supported studies are needed in this regard.

The most important feature that distinguishes infiltrative lesions from megacystic lesions is that infiltrative lesions have irregular borders and an edema effect can be seen in some, suggesting a tumor. Therefore, differential diagnosis from typical demyelinating lesions and the need for biopsy may be higher. However, the contrast enhancement pattern being peripheral rather than diffuse, like a tumor, may constitute a prediction that it has a demyelinating character. Although the demonstration of demyelination through biopsy in two patients removed us from the tumoral etiology, the situation that triggered this pathogenesis and the underlying cause could not be clarified before the patients died. This resulted in a higher mortality rate in our patient series, contrary to the literature. This group, in which the etiology was clarified due to the rapid progressive course and the prognosis of a patient who did not come to follow-up was unknown, constituted the group with the least conversion to MS in our study. Although it is difficult to reach any guiding conclusions in our limited patient experiment, we think that the contrast enhancement pattern plays an important role in the diagnosis of demyelinating disease in the differential diagnosis such as tumor, abscess or metastasis.

In this series, in the group in which we called the lesions "unclassified" because they resembled neither typical MS nor other atypical lesions in terms of size and shape, one of the patients was followed up with a diagnosis of Crohn's disease, and the other turned into clinical MS. Since our limited patient number compared to another study, in which $72.7 \%$ of patients didn't have another attack, we couldn't obtain a predictive data about prognosis of unclassified lesions but this may be due to different etiology of our patient group (22).

\section{Study Limitations}

In our study, although in a limited number, the presence of substance intoxication or secondary demyelinating disease groups such as Crohn's disease in some patients, the presence of patients followed-up with a diagnosis of ADEM, and patients who died without clarification of the diagnosis constituted limitations in terms of prognosis. However, based on these data, it might be possible to say that mortality and morbidity were not high among patients who presented with AIDL, had ring-like lesions, and converted to MS in the follow-up.

\section{Conclusion}

The diagnosis of atypical inflammatory demyelinating diseases, which we encounter in our clinical practice from time to time, will be easier, both with the development of MRI technologies and the detection of new biomarkers in recent years (aquaporin- 4 antibodies, which are diagnostic for neuromyelitis optica, and MOG antibodies detected in myelin oligodendrocyte-related diseases), and early diagnosis and appropriate treatment for the patient and the disease will contribute positively to the prognosis of these patients.

\section{Ethics}

Ethics Committee Approval: The study, conducted at Bakirkoy Prof. Dr. Mazhar Osman Mental Health and Neurological Diseases Hospital, was performed in accordance with the Helsinki Declaration and approved by the Local Ethics Committee (date: 22.05.2017/19124-00045685340).

Informed Consent: Patients were asked to sign an informed consent form that their information and follow-up would be entered into this database from the moment they were followed up.

Peer-review: Externally and internally peer reviewed.

\section{Authorship Contributions}

Concept: Z.Ö., E.A., A.S., Design: Z.Ö., E.A., A.S., Data Collection or Processing: Z.Ö., E.A., A.S., Analysis or Interpretation: Z.Ö., E.A., A.S., Literature Search: Z.Ö., E.A., A.S., Writing: Z.Ö., E.A., A.S.

Conflict of Interest: No conflict of interest was declared by the authors.

Financial Disclosure: The authors declared that this study received no financial support.

\section{References}

1. Thompson AJ, Banwell BL, Barkhof F, et al. Diagnosis of multiple sclerosis: 2017 revisions of the McDonald criteria. Lancet Neurol 2018;17:162-173.

2. Filippi M, Rocca MA, Ciccarelli O, et al. MRI criteria for the diagnosis of multiple sclerosis: MAGNIMS consensus guidelines. Lancet Neurol 2016;15:292-303.

3. Pittock SJ, Lennon VA, Krecke K, et al. Brain abnormalities in neuromyelitis optica. Arch Neurol 2006;63:390-396.

4. Barkhof F, Filippi M, Miller DH, et al. Comparison of MRI criteria at first presentation to predict conversion to clinically definite multiple sclerosis. Brain 1997;120:2059-2069.

5. Fazekas F, Barkhof F, Filippi M, et al. The contribution of magnetic resonance imaging to the diagnosis of multiple sclerosis. Neurology 1999;53:448-456.

6. Seewann A, Enzinger C, Filippi M, et al. MRI characteristics of atypical idiopathic inflammatory demyelinating lesions of the brain: a review of reported findings. J Neurol 2008;255:1-10.

7. Koelblinger C, Fruehwald-Pallamar J, Kubin K, et al. Atypical idiopathic inflammatory demyelinating lesions (IIDL): conventional and diffusionweighted MR imaging (DWI) findings in 42 cases. Eur J Radiol 2013;82:1996-2004.

8. Masdeu JC, Moreira J, Trasi S, et al. The open ring: A new imaging sign in demyelinating disease. J Neuroimaging 1996;6:104-107.

9. Masdeu JC, Quinto C, Olivera C, et al. Open-ring imaging sign: Highly specific for atypical brain demyelination. Neurology 2000;54:1427-1433. 
10. Gasperini C, Paolillo A, Rovaris M, et al. A comparison of the sensitivity of MRI after double- and triple-dose Gd-DTPA for detecting enhancing lesions in multiple sclerosis. Magn Reson Imaging 2000;18:761-773.

11. Smirniotopoulos JG, Murphy FM, Rushing EJ, et al. From the archives of the AFIP: patterns of contrast enhancement in the brain and meninges. Radiographics 2007;27:52551.

12. Stadelmann C, Ludwin S, Tabira T, et al. Tissue preconditioning may explain concentric lesions in Baló's type of multiple sclerosis. Brain 2005;128:979987.

13. Takai Y, Misu T, Nishiyama S, et al. Hypoxia-like tissue injury and glial response contribute to Balo concentric lesion development. Neurology 2016;87:2000-2005.

14. Balo J. Encephalitis periaxialis concentrica. Arch Neurol Psychiatry 1928;19:242-264.

15. Karaarslan E, Altintas A, Senol U, et al. Baló's concentric sclerosis: Clinical and radiologic features of five cases. Am J Neuroradiol 2001;22:1362-1367.

16. Wang C, Zhang KN, Wu XM, et al. Baló's disease showing benign clinical course and co-existence with multiple sclerosis-like lesions in Chinese. Mult Scler 2008; 14:418-424.
17. Bahn E, Maragkou T, Meer F, et al. Histopathological features of "cavitary" or "cystic" multiple sclerosis (MS) compared to classical MS. Mult Scler J 2017;23:976-1023.

18. Frequin STFM, Barkhof F, Lamers KJB, et al. The effects of high-dose methylprednisolone on gadolinium-enhanced magnetic resonance imaging and cerebrospinal fluid measurements in multiple sclerosis. J Neuroimmunol 1992;40:265-272.

19. Straub J, Chofflon M, Delavelle J. Early high-dose intravenous methylprednisolone in acute disseminated encephalomyelitis: A successful recovery. Neurology 1997;49:1145-1147.

20. Alexander M, Murthy JMK. Acute disseminated encephalomyelitis: Treatment guidelines. Ann Indian Acad Neurol 2011;14:1-10.

21. Martínez-Cáceres EM, Barrau MA, Brieva L, et al. Treatment with methylprednisolone in relapses of multiple sclerosis patients: Immunological evidence of immediate and short-term but not long-lasting effects. Clin Exp Immunol 2002;127:165-171.

22. Wallner-Blazek M, Rovira A, Fillipp M, et al. Atypical idiopathic inflammatory demyelinating lesions: Prognostic implications and relation to multiple sclerosis. J Neurol 2013;260:2016-2022. 